\title{
単純適応制御法による能唖制振*
}

\author{
日 野 満 司*1, 岩 井善 太*2 \\ 福 島浩 介*3, 若 宮 龍 市*2
}

\section{An Active Vibration Control by means of a Simple Adaptive Control Method}

\author{
Mitsushi HINO, Zenta IWAI, \\ Kousuke FUKUSHIMA and Ryuichi WAKAMIYA
}

\begin{abstract}
In this paper, we consider an active vibration control system based on a simple adaptive control (SAC) method when the system is subjected to bounded disturbances. The SAC method has advantages such that it requires little knowledge with respect to information about disturbances and plant-order when we construct a control system. However, the method was proposed only for tracking control problems. Hence, we first modified the usual SAC techniques to regulator control methods. Effectiveness of the proposed algorithm for the vibration control problems were confirmed by the experimental results obtained from the laboratory-scale experimental equipment of active vibration control. That is, the fundamental vibration suppression characteristics, such as robustness for the nonlinear friction and random disturbances, were attained by use of the modified SAC algorithm.
\end{abstract}

Key Words: Automatic Control, Vibration, Vibration Control, Active Control, Adaptive Control Simple Adaptive Control, Dynamic Vibration Absorber, Unknown Disturbance

\section{1. 緒}

能動制振系は機械，権造物等に生じる外乱による振 動をフィードバック制御等により除去しようとするも ので, 近年活発に研究がなされておりその有効性が模 証されつつある.

この場合の制御手法に関しては LQ 最適制御等によ る状態フィードバック制御系や，外乱除去の観点から 外乱が計測可能あるいは特定の外乱を対象とし外乱才 ブザーバで推定可能であるものとしてフィードフォワ

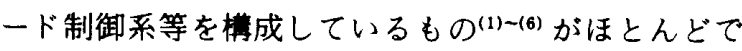
ある。しかし，それらの手法では高周波数領域および 特定の周波数に限ってはかなりの制振が達成できる が，広筙囲における周波数領域に対する高精度の制振 は不可能である。また，実在系では振動系パラメー夕 を正確に把握するのは難しく，さらに，外乱も未知情 報となる場合が多いため，従来の制御手法では一般的 な確定外乱が印加する振動系に対し良好な制振を達成 するのは困難である。

*原稿受付 平成 3 年 4 月 18 日.

*1 正员, 北九州工業高等尃門学校（8803 北九州市小合南区志 井 5-20-1).

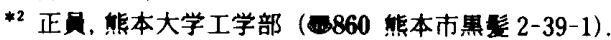

*3 正员, 東陶機器 (怢)（8802 北九州市小倉北区中島 2-1-1).
そのような場合の有力な制御手法として著者らはプ ラントパラメータおよび外乱パラメータが未知である 場合でも適用可能な内部モデル原理に基づく嗃応極配 置法を提案し実験においても良好な制振効果を㭘証し ている(7) (9). しかし，この手法は従来の適応極配置法 と比ベアルゴリズム゙かなり简単化されてはいるがそ れでも複蓶なものであり，非線形性の強いプラントへ の適用は困難であった。また，それを適用するに際し てはプラントおよび外乱特性多項式の次数が既知でな ければならず，その仮定が満たされない場合制振性能 が悪くなる場合があり,さらに従来の適応制御手法に おいて問題であった制御開始直後のパラメー夕推定過 程中における著しい制振性能の劣化傾向が改善されて いない。これらの欠点を克服する適応制御法として Sobel-Kaufmanらにより考案され(10), Bar-kanaに よって実用性が高められた(11) トラッキング制御を対 象とした単純適応制御法 (Simple Adaptive Control：以下 SAC と略記) がある。この手法はプラント が ASPR 条件 (Almost Strictly Positive Real Condition）なる条件を満たしていればプラントおよび外乱 に関する情報が未知でも適応制御系が単純な機檋で構 成でき非線形性に対してもかなりロバストであるとい う特徴を有している。 
そこで本研究では従来の規範モデルの介在するトラ ッキング問題を対象としたSACの優れた特長を制振 系に適用することを考え，そのために，同手法を制振 問題の 1 種であるレギュレータ問題に諦着させ能動制 振系へ適用することを検討する，また，その場合の制 御系の安定性の証明を行う。さらに，実験例によりそ のようにして構成した制御系の制振性能を検証する.

\section{SAC の椣成}

ここで採用する SACは Bar-kanaにより提案され たもの(11)であり,プラントの次数には無関係かつ従 来の適応制御法と比べ極めて単純なアルゴリスムで制 御系が楎成できる。さらにプラントに非線形性があっ ても非常に良好な制御性能が得られるという特徴を有 している。しかし，このSACはトラッキング問題を対 象としているため, そのままの形で制振問題に適用す ると規篹モデルが介在するため効率の悪いアルゴリズ ムとなってしまう。ここでは, Bar-kanaの手法を基 にしてレギュレータ問題を対象とするSACの構成法 を検討する。

$2 \cdot 1 \mathrm{SAC}$ プラントは次の $n$ 次可制御可観測な 1 入出力系で記述されるものとする.

$$
\begin{aligned}
& \dot{x}(t)=A x(t)+b u(t)+d w(t) \cdots \cdots \cdots \cdots \cdots(1 \cdot \mathrm{a})
\end{aligned}
$$

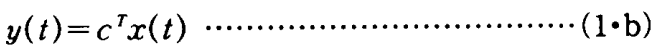

ここに, $A \in R^{n * n}, b, d, c \in R^{n * 1}$ は末知パラメータを 持つ行列とべクトルである.また, $x(t)$ は $n$ 次状態べ クトルであり, $u(t), y(t)$ は検出可能な入出力, $w(t)$ は末知有界外乱である。

ここで,プラントは次の仮定を満たしているものと する.

（i）プラントはASPR 条件を満たす。すなわち， あるフィードバック定数ゲイン $k^{*}$ が存在して,

$$
A_{c}=A+b k^{*} c^{T}
$$

とするとき, $G_{c}=c^{\tau}\left(s I-A_{c}\right)^{-1} b$ が強正実 $(\mathrm{SPR})$ と なる.

（ii）次式を満たす末知正定数 $\rho^{*}$ が存在する.

$$
\rho^{*}=\sup _{t}|w(t)|
$$

制御目的は振動系に混入する末知有界外乱 $w(t) に$ 上り励起されるプラントの振動変位 $y(t)$ を微小とす る制御入力を粠成することである。このための適応制 御則構成を以下に示す.

制御入力を次式で構成する.

$$
u(t)=k(t) y(t)
$$

ただし，可変出力フィードバックゲイン $k(t)$ は $\sigma$ 修 正項を付加した次の比例＋積分適応同定則で調整され
$ろ^{(12)}$.

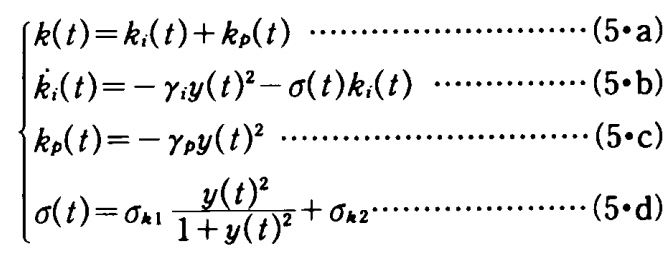

ここに, $\gamma_{i}, \gamma_{p}, \sigma_{k 1}, \sigma_{k 2}$ は正に与える設計パラメータ である。ただし， $\sigma_{k 2}$ は $k(t)$ の発散現象を抑制するも ので，本報告で新たに樂入したパラメータである.

この制御則を用いるとき, 制御系内の全信号は一様 終局有界となる.証明は付録に示す。さらに, 本制御則 は出力フィードバック制御系を㔍成しており可変出力 フィードバックゲイン $k(t)$ が式 $(5) よ り ~ y(t) \neq 0 て ゙$ ある限り時間とともにある值まで負に大きくなるた め, 制御系は結果的に外乱に対してロバストなハイゲ インフィードバック系となる。

2.2 ASPR 年件 プラントにSACを適用する に際してプラントは仮定（i ）の ASPR 条件を满たす 必要があるが、これを判定する手段として次の条件が ある。

式( 1 )で与えられているプラントが次の伝達関数 $G p(s)$ で表されるものとする.

$$
\begin{gathered}
G p(s)=B p(s) / A p(s) \\
=\sum_{j=0}^{m} b_{j} s^{j} / \sum_{i=0}^{n} a_{i} s^{i} \cdots
\end{gathered}
$$

このとき，次の条件が満たされていれば $G p(s)$ は ASPR である(12).

c. 1) $B p(s)$ が安定多項式

c. 2) $n-m \leqq 1$

c. 3） $n-m=1$ のとき最高位係数 $b_{m} / a_{n}$ が正

一般に実システムがこの条件を満足していることは 少ない。このような場合には図 1 に示すようにプラン と $G p(s)$ に対しフィードフォワード補偵を行うこと で搪張系 $G a(s)$ をASPR 化できることが Bar-kana によって提案されている(11). しかしこの場合，制御則 が制御対象とみなすのは搪張系 $G a(s)$ であるため, 本 来の出力 $y(t)$ に関して制御目的が達成される保証は

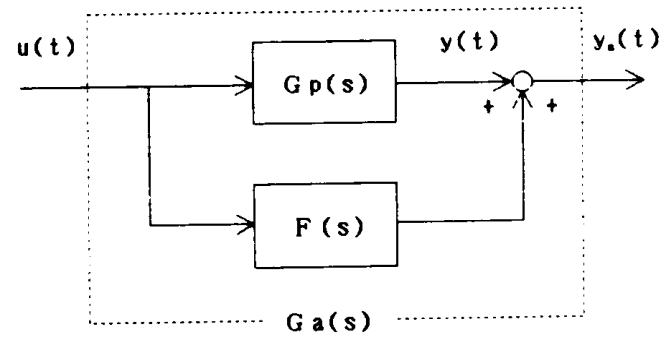

図 1 抎張系 
ない.したがって、フィードフォワード補償 $F(s)$ を使

用する周波数領域において,

$$
|F(j \omega)| \ll|G p(j \omega)|
$$

となるように設計すれば,

$$
y(t) \fallingdotseq y_{a}(t)
$$

となり実質的に $y(t)$ を制御することができる(12).

\section{3. 能助制 振系構成}

前述した制御手法は，機構は一般に複雑となるが制 御時に固定点を必要としないため広い適用簍囲を持つ 動吸振器形能動制振系に適用可能となる。ここでは, 図 2 に示したような実験装置の具体例について制御系 構成を説明する(9).これは主振動系質量と補助質量の 間にアクチェエータを取付けたもので, 出力が主振動 系質量の変位であり, 入力がサーボアンプへのコンピ ュータからの指令電圧である，制振原理は付加質量に アクチュエータによって外部から制振エネルギーを印 加し，付加質量を加速させた時に生じる力の反作用で 主振動系質量に力を与え外乱からの力を相殺させるこ とにより主振動系質量の制振を達成しょうとするもの である。

この振動系の方程式は次のようになる.

$M \ddot{y}+C \dot{y}+k_{1} y=k_{2}\left(w^{\prime}-y\right)-f-m \ddot{y}-F_{r}(\dot{y})$

$m \ddot{z}=f$

$こ こ に$,

$\begin{aligned} M & : \text { 主振動系質量 } \\ m & : \text { 補動質量 } \\ C & : \text { 粘性減衰係数 } \\ k_{i} & : \text { ばね定数 } \\ y & : \text { 中立点からの主振動系質量の変位 } \\ z & : \text { 主振動系質量に対するアクチュエータの制御 }\end{aligned}$

\section{入力相対変位}

$w^{\prime}$ : 中立点からの外乱変位

$f:$ アクチュエータから発生する力

$F_{r}$ : 主振動系貿量に作用する摩擦力

補助質量を駆動するアクチュエータとしては位置指 令形サーボモー夕を使用しているが，その動特性モデ ルは, 補助兵量 $m$ を同時に考虑した形で, 次の二次迤 れ系で与えるものとする。

$$
\ddot{z}=q_{1} \dot{z}+q_{2} z+r u
$$

ここで, る. 外乱項を $w$ として未知有界摩擦力 $F_{r}(\dot{y})$ をも含 めた形で

$$
w=k_{2} w^{\prime}-F_{r}(\dot{y})
$$

と定義し, 状態変数を $x^{T}(t)=[y(t), \dot{y}(t), z(t), \dot{z}(t)]$ と取ると式( 9$) \sim(11)$ は次の状態方程式で表される。

\begin{tabular}{|c|c|c|c|}
\hline Main ass & - & $M$ & 4.89 \\
\hline Sub ass & $\mathrm{kg}$ & - & 1.43 \\
\hline $\begin{array}{l}\text { Viscous danping } \\
\text { coefficient }\end{array}$ & Ns/n & C & 1.0 \\
\hline Spring constant & $N / \bullet$ & $\begin{array}{l}\mathbf{k}_{1} \\
\mathbf{k}_{2}\end{array}$ & $\begin{array}{l}163 \\
300\end{array}$ \\
\hline Actuat or & & $\begin{array}{l}q_{1} \\
\mathbf{q}_{2} \\
\mathbf{r}^{2}\end{array}$ & $\begin{array}{l}-25.9 \\
-47.5 \\
0.387\end{array}$ \\
\hline
\end{tabular}

$$
\begin{aligned}
& \left\{\begin{array}{l}
\dot{x}(t)=A x(t)+b u(t)+d w(t) \\
y(t)=c^{T} x(t) \ldots \ldots \ldots \ldots \ldots \ldots \ldots \ldots \ldots \ldots
\end{array}\right. \\
& A=\left[\begin{array}{cccc}
0 & 1 & 0 & 0 \\
a_{1} & a_{2} & a_{3} & a_{4} \\
0 & 0 & 0 & 1 \\
0 & 0 & q_{2} & q_{1}
\end{array}\right], b=\left[\begin{array}{c}
0 \\
b_{1} \\
0 \\
r
\end{array}\right], d=\left[\begin{array}{c}
0 \\
d_{1} \\
0 \\
0
\end{array}\right] \\
& c^{T}=\left[\begin{array}{llll}
1 & 0 & 0 & 0
\end{array}\right]
\end{aligned}
$$

$$
\text { 表 } 1 \text { パラメー夕概略值 }
$$

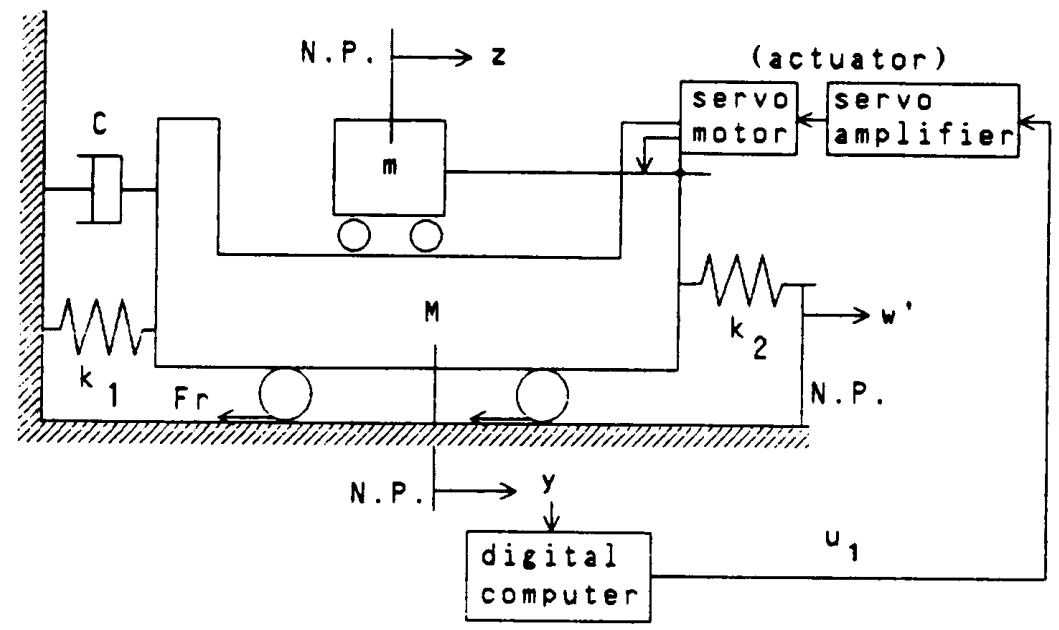

図 2 動吸振器形能動制振系 
ただし, 式中の記号は次のとおりである.

$$
\begin{aligned}
& a_{1}=-\frac{k_{1}+k_{2}}{M+m}, a_{2}=-\frac{C}{M+m} \\
& a_{3}=-\frac{m q_{2}}{M+m}, a_{4}=-\frac{m q_{1}}{M+m} \\
& b_{1}=-\frac{m r}{M+m}, d_{1}=\frac{1}{M+m}
\end{aligned}
$$

なお,このシステムは可制御可観測である.

実験で使用する装贯のプラントおよびアクチュエー 夕のパラメー夕概略值は表 1 のとおりである.

このプラントに対して SACを適用することを考え る.プラントの入出力に関する伝達関数は次式で表さ れる.

$$
G p(s)=\frac{b_{1} s^{2}}{\left(s^{2}-q_{1} s-q_{2}\right)\left(s^{2}-a_{2} s-a_{1}\right)}
$$

このプラントは仮定 c 。1)，c，2）を満たしておらず ASPR 条件を満足していない.したがってフィードフ オワード補供を施しプラントをASPR 化する，さら に，条件式(7) を満足するようにするために図 3 に示 すようにプラントに負の入力 $u_{1}(t)=-u(t)$ を与え る.フィードフォワード補偵として次の一次遅れ系を 考える。

$$
F(s)=\frac{\beta}{s+\alpha}, \alpha, \beta>0
$$

このとき，搪張系は次式となる.

$$
\begin{aligned}
& G a(s)= \\
& \frac{\beta\left(s^{2}-q_{1} s-q_{2}\right)\left(s^{2}-a_{2} s-a_{1}\right)-b_{1} s^{2}(s+\alpha)}{(s+\alpha)\left(s^{2}-q_{1} s-q_{2}\right)\left(s^{2}-a_{2} s-a_{2}\right)}
\end{aligned}
$$

この拡張系は仮定 C . 2)，c．3）を満たしている．また， 分子多項式を安定とする $\alpha, \beta$ の覜囲は表 1 のパラメ 一夕概略值からフルビッツの安定判別法を用いて次の ように求められる。

$\alpha>1.82,0<\beta<4.45 * 10^{-3}$

ここでは,この籁曲内で根軌跡法により $\alpha, \beta$ の值が 零点へ与える影䇺を調べ安定度が高く条件式 ( 7 )を満 足するものとして次の值を採用した。

$$
\alpha=7.0, \beta=1.0 * 10^{-4}
$$

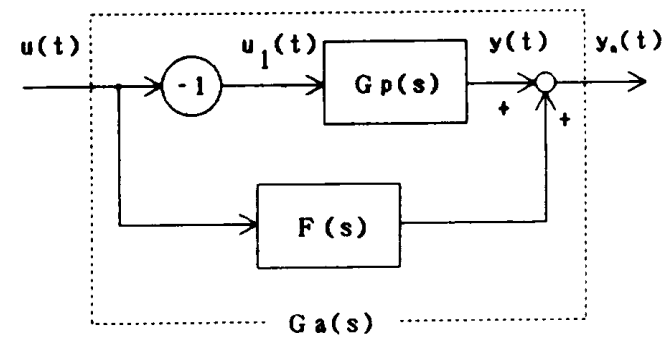

図 3 拡張系
フィードフォワード補僙のパラメータ選定に際して プラントパラメータの值が必要ではあるが, SACで はフィードバックゲインを適応的に調整しているため プラントパラメータ值にはかなりロバストなシステム となっている.そのため, プラントパラメータ值が，も し, 真值とかなり違っていても, 式(15)によって ASPR 条件さえ満足されておれば制振は十分に達成 される。

\section{4. 实}

4 -1 实弱装目実験装嘈の概略は既に図 2 に示 した。加振源としては外乱発生装圈により $w^{\prime}(t)$ を発 生させ主振動系質量にばね $k_{2}$ を介して印加する。主振 動系質量変位は差動トランスで検出し，ノイス処理用 フィルタと $\mathrm{A} / \mathrm{D}$ 変換器を介して計算機 (MELCOM $70 \mathrm{MX} / 2600)$ に取り込まれる。計算機内で制御アルゴ リズムに従って処理された信号は D/A 変換されたサ ーボアンプを介してサーボモー夕に送られ，ボールね じを介し補助質量を直線的に駆動させる装置となって いる。検出から制御までの 1 サンプリング時間はこの 場合約 $3.1 \mathrm{~ms}$ であった. 文献（9）に示した通常の適応 則を用いた場合には同じ計算機で $60 \sim 110 \mathrm{~ms}$ を要し たのに比べ計算時間は大幅に短縮されているが,これ

\begin{tabular}{|c|c|c|c|c|c|}
\hline $\begin{array}{l}\text { 实桹 } \\
\text { 员目 }\end{array}$ & $\gamma_{1}$ & $\gamma_{p}$ & $k_{y}(0)$ & $\sigma \times 1$ & $\sigma_{k 2}$ \\
\hline (a) & $1 * 10^{8}$ & $1 * 10^{\circ}$ & -3000 & 0.1 & 0 \\
\hline (b) & $1 * 10^{\circ}$ & $1 * 10^{7}$ & 0 & 0.1 & 0.0015 \\
\hline (c) & $3 * 10^{8}$ & $3 * 10^{\circ}$ & 0 & 0.1 & 0.008 \\
\hline
\end{tabular}
は, 通常の適応制御方式では 12 個のパラメータ同定 を同時に行う必要があったのに対し，提案する SAC 手法では可変出力フィードバックゲイン 1 個を適応的 に同定すればよいことに起因している。なおここで はミニコンピュータを使用したが，SAC 方式を用い れば通常のパーソナルコンピュータでも短い時間で十

表 2 制御則の設計パラメータ

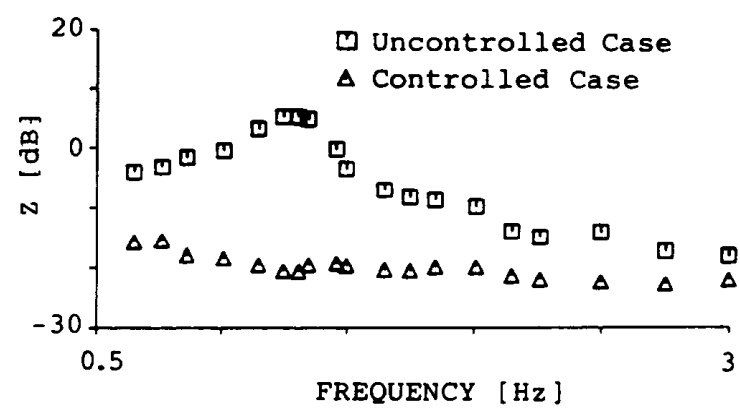

図 4 周波数応答 
分処理できる計算量となる。

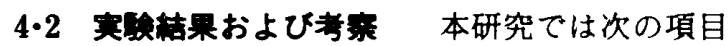
について実験を行った。

（a）外乱周波数を変化させたときの主振動系質量 変位の周波数特性

（b）不規則な外乱が印加された場合

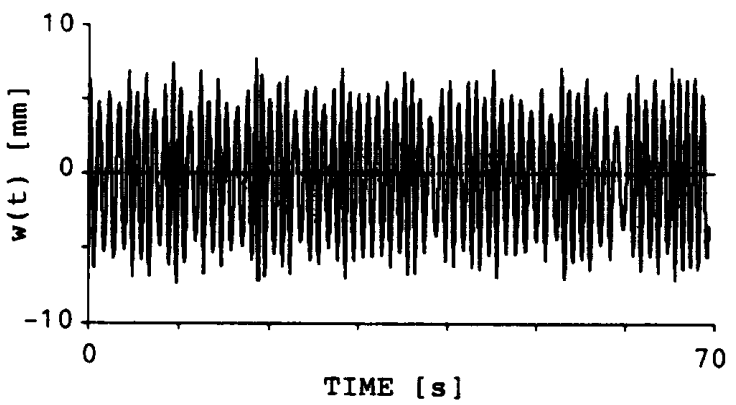

(a) 外乱変位

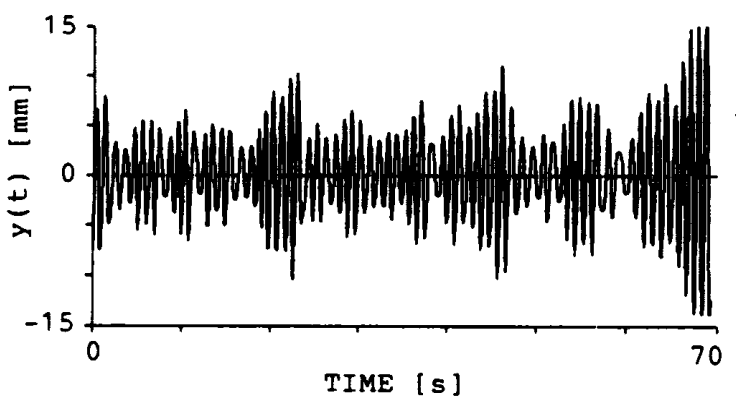

（b） 無制御時の主振勘系面量变位

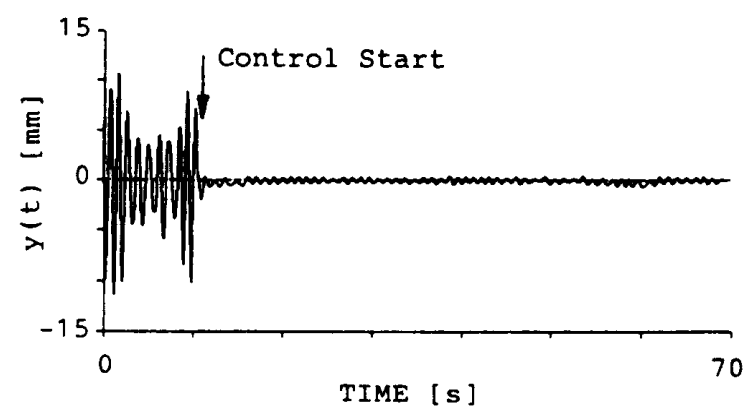

（c）制御時の主振娌系䆩变変位

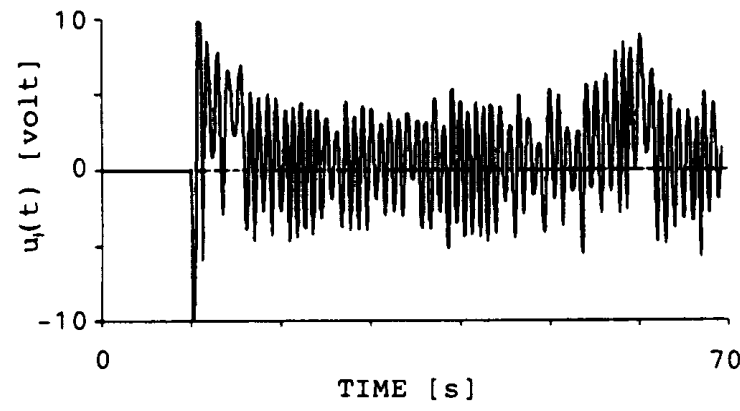

（d）制御指令西圧

図 5 不規則な外乱を印加した時の制御効果 （c）制振中に主振助系孹量に突発的な外乱が与え られた場合

各項目における制御則の設計パラメータは表 2 のと おりである。

以下，各実験項目に従って実験結果および考察を示 す.

（a）外乱を振幅 $9.3 \mathrm{~mm}$ の正弦波 1 成分とし角速 度を共振周波数 $(8.04 \mathrm{rad} / \mathrm{s})$ を含み $4.08 \mathrm{rad} / \mathrm{s}$ から $18.9 \mathrm{rad} / \mathrm{s}$ まで変化させた時の周波数応答を図 4 に示 す。ただし，就軸 $z$ は次に定義するように主振動系質 量の基本周波数における変位の絶対值の最大值と外乱 のそれの比をデシベル值で表したものである。

$$
\begin{gathered}
Z=20 \log _{10}(Y / W) \\
Y=\max \mid \text { 主振動系質量の基本周波数における } \\
\text { 出力変位 } \mid
\end{gathered}
$$$$
W=\mid \text { 外乱の振幅変位 } \mid
$$

この周波数範囲では制御を行った場合のほうが振動レ ベルが無制御時の場合に比べ低レベルになっており, 良好な制振効果が得られている。高周波数外乱に関し ては本実験装置の外乱発生に限界があるのでデー夕は 示していないが, この場合システム自体が低域フィル 夕特性を持つので特に制御を行わなくても振動変位は 微小となる。一方，低周波数外乱に対しては制御効果 は劣化する。これは実験系が主振動系質量変位を補助 質量系の加速度変化で制御する一種の動吸振器構造を



（a）主振虭系筫变位

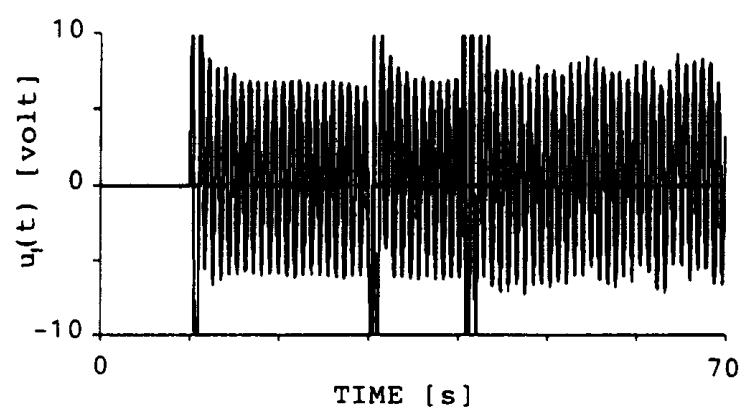

（b）制御指令電压

図 6 突発的外乱を印加した時の制御効果 
取っているためであり，その結果，低周波数領域では 大きなストロークを発生させることが必要となるが， 装置上限界があるため実際には制御できなくなるため である，以上より本実験系に関する限り，制振効果は 共振点を含むある周波数篹囲に限定される。したがつ て，実際にはこのようなシステムにおいてはある周波 数領域内の振動に限定して制御アルゴリスムを駆動さ せる等の工夫が必要となるものと思われる。

（b）不規則な外乱波形を与えた時の結果の一例を 図 5 に示す。この波形は正弦波外乱の振幅および角速 度を 1 周期ごとにガウス分布に従って不規則に変化さ せることにより発生させた，振幅については絶対值の

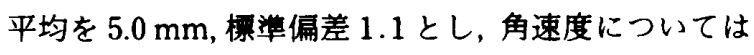
平均 $7.0 \mathrm{rad} / \mathrm{s}$, 標準偏差を 1.0 と設定した. 制御を行 っていない時の主振動系質童変位の挙動はかなり乱れ たものとなっている。この場合も制御開始後直ちに原 点へ収束し微小振動を持続しており良好な制振効果が 得られている。また，従来の適応制御手法を適用した 場合(9)にみられた制御開始直後の大きな振幅変化は ない.

(c) 振幅 $9.3 \mathrm{~mm}$, 角速度 $6.91 \mathrm{rad} / \mathrm{s}$ の正弦波外乱 を加えて制御中に 2 回にわたり突発的な変化を主振動 系質量に与えた場合の結果を図 6 に示す. 突発的外乱 を与えるとその力により主振䡃系質量振幅は変動する がその変功は直ちに隇少している。

上述の実験結果から次のことが結論できる．すなわ ち外から加えられる各種の外乱に対し, SACを用い た場合には、これまでの適応制御則に基づいた振動抑 制法(7) (9) に比べ制振性能は大幅に改善される.その理 由としては，まず，前述したように同定すべきパラメ 一夕個数が基本的には 1 個であるため 1 サンプリング 当たりの適応制御アルゴリスムの計算量が少なく、計 算精度向上とサンプリング時間の短縮な同時に図られ たことが考えられる. 次に，理論的には適応八イゲイ ン出力フィードバック檄造となるため ${ }^{(12)}$, 有界な未知 摩摖項を含む外乱の影䇾全体が出力のハイゲイン係数 によって結果的には大きく抑制され，ロバスト化が達 成されたものと考えられる。

\section{5. 結}

本研究では能動制振系として動吸振器形能動制振系 にSACを適用することを検討しその有用性を実験に より検証した。まず，従来のSACは規節モデルを含む トラッキング制御問題として定式化されているが, 制 振問題に必要なレギュレー夕問題に㷌着させるために 規範モデルを削除することを検討し，アルゴリスムを

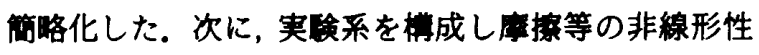
が存在し,かつ, 各租の外乱が印加した场合でも高性 能な制振効果が得られることを検証し，提案する制御 則が制振系楼成に四しロバストであり，実在系の制振 問題への道用に際して非常に有効な制御則となり得る 可能性を示した.

旪後に実験に協力された熊本大学学生 蒲原清隆氏 に対し感謝の意を表する。

\section{付徐、制御系内の全信号の有界性の柾明}

式(1・a)のプラントに理想的なフィードバックゲイ ン $k^{*}$ を学入し式 $(1 \cdot \mathrm{b})$ と制御入力式 $(4)$ を用いると 次のように変形できる.

$$
\dot{x}(t)=A_{c} x(t)+b\left\{k(t)-k^{*}\right\} y(t)+d w(t)
$$

ここで, 右辺第 2 項を

$$
\zeta(t)=\zeta_{i}(t)+\zeta_{p}(t)=k(t)-k^{*}
$$

と定戠すると，プラントは次式で表される.

$$
\begin{aligned}
& \dot{x}(t)=A_{c} x(t)+b \zeta(t) y(t)+d w(t) \cdots \cdots(19 \cdot \mathrm{a}) \\
& y(t)=c^{T} x(t) \cdots \cdots \cdots \cdots \cdots \cdots \cdots \cdots \cdots \cdots \cdots \cdots \cdots \cdots \cdots \cdots \cdots \cdots \cdots \cdots \cdots \cdots \cdots \cdots \cdots
\end{aligned}
$$

まず, $x(t), \zeta_{i}(t)$ の一様終局有界性を示す. 式(18)および式( 5 )ょり次式を得る.

$$
\begin{aligned}
& \dot{\zeta}_{i}(t)=\dot{k}_{i}(t) \\
& \quad=-\gamma_{i} y(t)^{2}-\sigma(t) \zeta_{i}(t)-\sigma(t) k^{*} \quad \cdots \cdots(20 \cdot \mathrm{a}) \\
& \zeta_{p}(t)=k_{p}(t)=-\gamma_{p} y(t)^{2} \cdots \cdots \cdots \cdots \cdots \cdots \cdots(20 \cdot \mathrm{b})
\end{aligned}
$$

いま, 正定対称行列 $P$ を考え, 次の正定スカラ闺数を 馗入する。

$$
V(t)=x(t)^{T} P x(t)+\gamma_{i}^{-1} \zeta_{i}(t)^{2}
$$

プラント式(19)が ASPR 条件を满たしているため, Kalman-Yakubovichの補題から次の関係式が成り 立つ.

$$
A_{c}{ }^{T} P+P A_{c}=-Q, b^{T} P=c^{T}
$$

ここにQは正定行列である.ここで, $V(t)$ の時間微 分を取り，式(19・a)〜 (22)を用いると次式を得る.

$$
\begin{aligned}
& \dot{V}(t)=-x(t)^{T} Q x(t)-2 \gamma_{p} y(t)^{4}+2 w(t) d^{T} P x(t) \\
& \quad-2 \sigma(t) \gamma_{i}^{-1} \zeta_{i}(t)^{2}-2 \sigma(t) k^{*} \gamma_{i}^{-1} \zeta_{i}(t) \\
& \quad \leqq-x(t)^{T} Q x(t)+2 w(t) d^{T} P x(t) \\
& \quad-2 \sigma(t) \gamma_{i}^{-1} \zeta_{1}(t)^{2}-2 \sigma(t) k^{*} \gamma_{i}^{-1} \zeta_{i}(t) \cdots \cdots(23)
\end{aligned}
$$

行列*の固有值の最大值 (最小值)を $\lambda_{\max }[*]\left(\lambda_{\min }[*]\right)$ と表すと上式は次式で評価される.

$$
\begin{aligned}
& \dot{V}(t) \leqq-\lambda_{\min }[Q]\|x(t)\|^{2}+2 \rho^{*} \lambda_{\max }[P]\|d\| \\
& \|x(t)\|-2 \inf _{t}\{\sigma(t)\} \gamma_{i}^{-1}\left|\zeta_{i}(t)\right|^{2} \\
& \quad+2 \sup _{t}\{\sigma(t)\}\left|k^{*}\right| \gamma_{i}^{-1}\left|\zeta_{i}(t)\right| \cdots \ldots \ldots \ldots \ldots \ldots
\end{aligned}
$$

さらに

$$
\eta(t)=\left[\|x(t)\|,\left|\zeta_{i}(t)\right|\right]^{T}
$$




$$
\begin{aligned}
& S_{1}=\min \left[\lambda_{\min }[Q], 2 \operatorname{2inf}\{\sigma(t)\} \gamma_{i}{ }^{-1}\right] \\
& S_{2}=\max \left[2 \rho^{*} \lambda_{\max }[P]\|d\|, 2 \sup \{\sigma(t)\}\left|k^{*}\right| \gamma_{i}{ }^{-1}\right]
\end{aligned}
$$

とおくと式(24)は次式で表される。

$$
\dot{V}(t) \leqq-S_{1}\|\eta(t)\|^{2}+S_{2}\|\eta(t)\| \cdots
$$

ここで， $S_{1}$ は正の值を持つことからCorless-Leitmann の定理 ${ }^{(13)}$ が適用でき， $\eta(t)$ の一様終局有界性 がいえ，したがって $x(t) ， \zeta_{i}(t)$ の一様終局有界性がい える.

次に, $y(t)$ と $k(t)$ の一様終局有界性の証明を行う. 式(19・b)より，

$$
|y(t)| \leqq\|c\|\|x(t)\|
$$

と評価されるので $y(t)$ も一様終局有界である。また， 制御則の可変出力フィードバックゲインについても式 $(5 \cdot \mathrm{a}),(18),(20 \cdot \mathrm{b})$ より

$$
|k(t)| \leqq\left|k_{i}(t)\right|+\left|k_{p}(t)\right|
$$

$$
\leqq\left|k^{*}\right|+\left|\zeta_{i}(t)\right|+\gamma_{p}|y(t)|^{2}
$$

と評価できるので $k(t)$ も様終局有界である.以上で 制御系内の全信号の有界性が証明された。

\section{文献}

（1）背戸・ほか 2 名，機論，57-534，C(1991)，478

（2）吉田・ほか5 名, 文献(1)の 472 ページ.

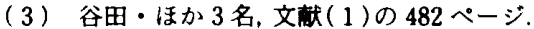

（4）水野・荒木，計自論，26-6(1990)，692.

（5）西村・ほか 2 名, 機猃, 55-517, C(1989)，2321

（6）岩井・ほ加 4 名, 機論, 54-505, C (1988)，2107。

（7）日野・岩井, 計自諭, 25-7, (1989), 821.

（8）日野・は加2名, 機論, 57-533，C(1991)，94.

（9）日野・ほ加2名，機論，57-537，C(1991)，102.

(10) Sobel, K., Kaufman, H. and Mabius, L., IEEE Trans. Aeros. Electron. Syst., AES-18-5, (1982), 576.

(11) Bar-kana, I., Int. J. Adaptive Control and Signal Processing, 1, (1987), 95.

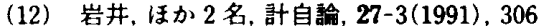

(13) Corless, M. and Leitmann, G., IEEE Trans. Autom. Control, AC-26, (1981), 1139 